\title{
Review
}

\section{Detection and Control Bacteria Cause Grain Rot Burkholderia glumae on Rice}

\author{
Syahri')*, Renny Utami Somantri ${ }^{1)}$, \& Priatna Sasmita ${ }^{2)}$ \\ ${ }^{1)}$ South Sumatera Assessment Institute for Agricultural Technology (South Sum. AIAT) \\ Jln. Kol. H. Barlian No. 83 Km. 6 Palembang, South Sumatera 30153 Indonesia \\ 2) Indonesian Center for Rice Research (ICRR) \\ Jln. Raya 9, Sukamandi, Subang, West Java 41256 Indonesia \\ *Corresponding author.E-mail: syahrihpt@gmail.com
}

Received August 2, 2018; revised April 4, 2019; accepted August 1, 2019

\begin{abstract}
Burkholderia glumae, before mid-2018, is categorized as plant quarantine pest A2 Group 1 that its existence has been detected in Indonesia. B. glumae has been known to spread in the central production of rice in Java, Sumatra, Borneo dan Sulawesi. This review aimed to explain the strategies for B. glumae detection through its characteristics and to prevent the divergence of this bacterium in Indonesia. The previous studies reported that the bacteria could reduce yield up to $75 \%$ and caused the decrease of weight-grain or the increase of empty grain. The disease intensity is affected by environmental and physiological factors such as warm temperature at nighttime and high rainfall intensity. The optimum temperature for the development of the disease is $30-35^{\circ} \mathrm{C}$. Moreover, the pathogen could survive at a temperature of $41^{\circ} \mathrm{C}$. The tropical area of $32-36^{\circ} \mathrm{C}$ are suitable for $B$. glumae. Recently, the effective control of the disease in the field has not been found yet. Meanwhile, early detection of the disease is not yet determined, even though it is necessary to prevent its spread in rice cultivation in Indonesia. Detection of the disease by Agricultural Quarantine Agency as a frontline is needed to check the entry of the disease carried by the import activities of the seed. Detection in the suspected field by protection institutes through frequent surveillance in central production areas of rice should be considered as an important task. The effective techniques to prevent $B$. glumae are the use of resistant varieties, the practice of seed treatments (using antibacterial, bactericide, heat treatment or plant extract), and the application of oxolinic acid to the crops.
\end{abstract}

Keywords: Burkholderia glumae, control method, detection strategies, grain rot, quarantine

\section{INTRODUCTION}

The grain rot of rice, previously classified as a plant quarantine pest, is one of the serious threats to the national rice production. Handiyanti et al. (2018) stated that grain rot caused by Burkholderia glumae was detected in rice varieties from several locations in Java, i.e. IR64 from Purworejo, Ciherang from Cirebon, and Inpari Sidenuk from Banyuwangi. $B$. glumae is a plant pathogenic bacterium cause blight symptoms in rice panicles, seed rot, and wither on plants (Nghiep et al., 2001; Sayler et al., 2006; Kim et al., 2010). Sayler et al. (2006) also reported that $B$. glumae is transmitted through infected seeds. $B$. glumae was first discovered in Japan as a cause of grain rot and blight on seedlings and thereby being an important disease of rice in Japan (Rush, 2007).

According to Ministry of Agriculture Regulation No. 51/Permentan/KR.010/9/2015 concerning the types of plant quarantine pests, $B$. glumae classified into plant quarantine pest A2 Group I which means that it is already a presence in Indonesia, yet cannot be controlled by any treatment. However, after the issuance of Permentan No. 31/Permentan/KR.010/ $7 / 2018$ concerning types of plant quarantine pests, $B$. glumae has been removed from the list of plant quarantine pests. This indicates that $B$. glumae has spread to central rice production in Indonesia. In addition, B. glumae has become an issue in various countries, i.e. Korea, Japan, the USA, and other Asian countries (Kim et al., 2012). B. glumae distribution areas include Indonesia (Java, Sumatra, Kalimantan), Asia (China, Taiwan, Japan, Korea, Philippines, Sri Lanka, Vietnam), America (Colombia, Panama, USA), and Africa (Burkina Faso) (Peraturan Menteri Pertanian No. 51 Tahun 2015). In the southern United States, this disease caused a loss yield by 40\% during 1995 and 1998, and even in some places up to $80 \%$ (Fang et al., 2009; Ham et al., 2011; Nandakumar et al., 2009; Shahjahan et al., 2000a; Zhou et al., 2011). 
Trung et al. (1993) reported that $B$. glumae can reduce rice yield by up to $75 \%$ for reducing grain weight, empty grains, and inhibition of seed germination.

Government efforts to prevent the entry of bacteria cause grain rot continues to be done through the role of the Plant Quarantine Agency. BBKP Surabaya has prevented the entry of imported Chinese seeds infected by B. glumae in 2014. In the following year, BBKP Soekarno-Hatta also succeeded in preventing the entry of rice seeds from China and the Philippines which were infected by B. glumae (Barantan, 2015). Therefore, this paper was aimed to inform about the detection technique of $B$. glumae through its characteristics, efforts to prevent the spread, and appropriate control in rice cultivation in Indonesia.

\section{BIOECOLOGY}

The scientific classification of B. glumae is (Ballard et al., 1970; CABI, 2017):

\begin{tabular}{|c|c|}
\hline Phylum & : Proteobacteria \\
\hline Class & : Betaproteobacteria \\
\hline Order & : Burkholderiales \\
\hline Family & : Burkholderiaceae \\
\hline Genus & : Burkholderia \\
\hline Species & : Burkholderia glumae \\
\hline
\end{tabular}

(Kurita \& Tabei, 1967)

B. glumae is a gram-negative bacterium, which was previously known as Pseudomonas glumae Kurita and Tabei (Yuan, 2004; Nandakumar et al., 2009; Pinson et al., 2010). B. glumae is a non-fluorescent bacterium that produces a green-yellow color, the water-soluble pigment in various media, and rodshaped bacteria with 1-3 flagella. In the media, bacterial colonies produce grayish-white or yellow pigments (Yuan, 2004) (Figure 1).

Grain rot caused by B. glumae is transmitted through seeds (Goto \& Ohata, 1956; Uematsu et al., 1976) and epiphytes develop in plants, especially in the maturity of rice stadia. Bacteria will develop quickly on the surfaces of newly emerged panicles and infect the flowers. The initial symptoms are small rot of $1-5 \mathrm{~mm}$ with brown edges on the leaves and panicles, hence caused the empty grains (Sayler et al., 2006; Pinson et al., 2010; Ham et al., 2011). B. glumae produces toxoflavin toxin at a temperature of $30-38^{\circ} \mathrm{C}$, which inhibit the growth of leaves and roots of rice, and chlorosis in panicles (Iiyama et al., 1995; Jeong et al., 2003; Suzuki et al., 2004). B. glumae can be found in air, soil, and water. The spread of $B$. glumae in the soil is strongly influenced by soil type, $\mathrm{pH}$, cultivated plants, and weather. B. glumae can survive on plants during the growing season, on rice seeds stored at room temperature or even on weeds and parts of rice plants left in the field after harvesting (Yuan, 2004). Then, diseases can develop after rice plants are planted in the field. B. glumae are non-obligate hence they can live on the plants left in the field and they become the source of infection in the next growing season.

\section{FACTORS AFFECTING DEVELOPMENT OF DISEASES}

The severity of grain rot highly depends on weather conditions at the flowering stadia (Tsushima et al., 1996). The infection will increase in high humidity and high temperatures. Several factors can affect plant susceptibility, such as the flowering duration of the variety. According to Tsushima (2011), rice plants are very susceptible to infection within 1-3 days after flowering. However, plants survive in 2 days before flowering and 4 days after flowering. In addition, plants are also susceptible to $4-5$ days after the heading time to 11 days afterward. Infection rapid spread if humidity is high ( $>95 \%$ ), otherwise symptoms will not appear if humidity is $<70 \%$ (Tsushima et al., 1995; Tshushima, 1996).

Disease development is strongly influenced by environmental conditions and plant physiology (Tshusima, 1996; Pinson et al., 2010). Low temperatures inhibit disease progression and increase the development of the wax layer on the cuticle of the host plant thus it may have a role to increase plant resistance. The disease can develop rapidly in unusual environmental conditions, such as high temperatures, especially at night with heavy rain (Zeigler \& Alvarez, 1990; Mew, 1992). The optimal temperature for disease development is $38-40^{\circ} \mathrm{C}$ (Nandakumar et al., 2009) or $30-35^{\circ} \mathrm{C}$ (Kurita et al., 1964; Tsushima et al., 1986) even at $41^{\circ} \mathrm{C}$ (Saddler, 1994 cit Zhou-qi et al., 2016). Thereby, the disease incidence is very high in tropical areas including in Indonesia which has an average maximum temperature of $32-36^{\circ} \mathrm{C}$.

The high humidity in the flowering stadia also increases disease infection and the attack of B. glumae could be worse during global warming (Tsushima et al., 1995; Ham et al., 2011). The severity of the disease is also influenced by internal and external factors, i.e. plant susceptibility and inoculum 

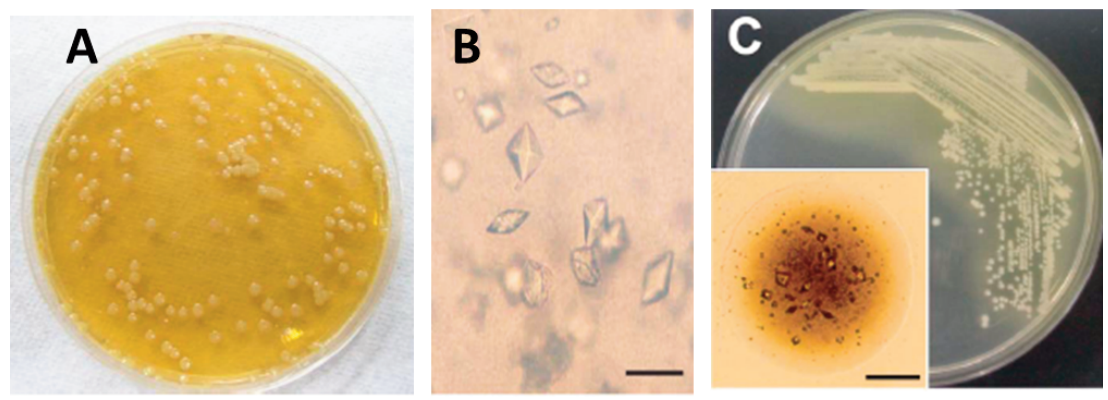

Figure 1. A and C are bacterial colonies on the media (Kim et al., 2010; Niño, 2014) and B is the toxoflavin crystal produced (Kim et al., 2010)
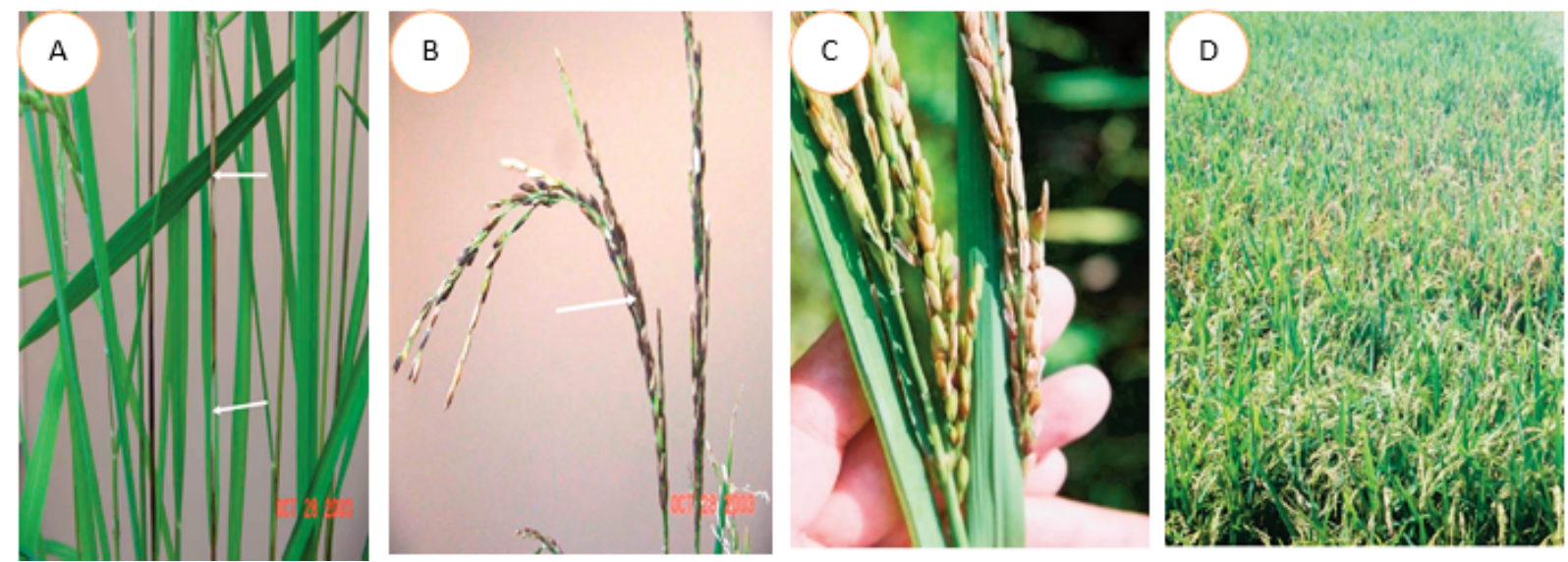

Figure 2. The symptoms of grain rot caused by Burkholderia glumae on the midrib of the leaves (A), rice panicle (B), panicle discoloration (C), and the disease symptoms in the field (D) (Yuan, 2004)

density of the pathogen (Tsushima, 1996). The severity of the disease will greatly increase if the rice is susceptible and very high inoculum density. According to the rainfall and temperature pattern in Indonesia, B. glumae will potentially spread easily in Indonesia. Therefore, early warning of the grain rot is necessitated, mainly through the use of existing climate data. The use of an integrated cropping calendar system created by the Indonesian Agency for Agricultural Research and Development can be used to determine the right cropping season, cultural practices that inhibit disease development, and the development of early disease detection in the field.

\section{SYMPTOMS OF GRAIN ROT DISEASE}

B. glumae attacks various parts of rice plants, such as leaves and grains, causes wilting or rot of the leaves (Figure 2A), and cause discoloration, empty grains, dark spots, and rot on the grains (CABI, 2017). Yuan (2004) stated that B. glumae can cause rot on grain, seedling, and midrib of the rice. The specific symptom of $B$. glumae is a blight on panicles accompanied by the color-changing (usually brown-grey), the empty grain, upright panicles with straw-colored, and eventually the midrib turn gray lesion with a reddish-brown margin (Nandakumar et al., 2009) (Figure 2B). These symptoms in the field are similar to the symptoms caused by stem borer and neck blast disease.

The disease can occur through primary or secondary infections. Primary infection occurs when the infected seeds are planted in the field. Meanwhile, secondary infection occurs when surrounding plants near the source of infection are infected by the disease. After infection, the panicles color will change from green to reddish-brown (Mizobuchi et al., 2013). Tsushima (2011) stated that pathogens initially colonize the lower surface of the lodicule and the inner surface of the lemma. When attacking in the flowering stadia, the bacteria will cause empty grains. 


\section{DETECTION METHOD}

Detection of plant diseases is necessary to determine the cause of disease hence the most effective control technique could be conducted. The accuracy of disease detection will determine the effectiveness of the used control technique. The misdetection causes control to be ineffective. The first effort to detect disease is by recognizing the symptoms of the disease. The specific symptoms can be used as an indicator to determine the pathogen. However, the symptoms appear in the field are usually similar hence difficult to distinguish. Especially if the observations are late to be done thereby the symptoms appear are caused by secondary causes. Therefore, the right time of observation is the key to knowing the symptoms caused by B. glumae.

For the accuracy of $B$. glumae detection, Barantan (2015) has a recommendation for testing B. glumae through the use of the culture method as a confirmation test method. Whereas Tsushima et al. (1986) have developed semi-selective media known as SP-G media. Furthermore, Kawaradani et al. (2000) found a selective medium for accessing $B$. glumae, this medium known as CCNT, in 1,000 $\mathrm{ml}$ of sterile water contains of $2 \mathrm{~g}$ of yeast extract, $1 \mathrm{~g}$ of polypepton, $4 \mathrm{~g}$ of inositol, $10 \mathrm{mg}$ of cetrimide, $10 \mathrm{mg}$ of chloramphenicol, $1 \mathrm{mg}$ of novobiocin, $100 \mathrm{mg}$ of chlorothalonil, and $18 \mathrm{~g}$ of agar. After being incubated for $2-4$ days at $41^{\circ} \mathrm{C}, B$. glumae will produce a yellowish colony on the media which is different from other bacteria species. This result is considered to be useful to ensure the cause of the disease accurately if the symptoms are difficult to distinguish.

The development of selective media is often constrained by a large number of microorganisms in nature (Andrews \& Harris, 2000; Torsvik \& Øvreås, 2002), thus often causing the growth of other organisms on these selective media (Alvarez, 2004). Therefore, Kawanishi et al. (2011) developed a selective media known as SMART (Selective Mediumdesign Algorithm Restricted by Two constraints). SMART media were developed not from natural ingredients that act as selectors and contain two ingredients (carbon and antimicrobials). Besides being able to detect the presence of B. glumae, SMART is also able to recognize the ecology and epidemiology of the target bacteria.
Kim et al. (2012) stated that the detection procedure for B. glumae bacteria could be done through the bio-PCR method. Previously, Sayler et al. (2006) have developed an effective PCR method for detecting B. glumae in seeds and in plants. PCR and real time-PCR have been used as the main method to identify several Burkholderia species originating from the soil, water, infected plants, and mammalian cells (Hikichi et al., 2001; Furuya et al., 2002; Sayler et al., 2006). The PCR primer based on $16 \mathrm{~S}-23 \mathrm{~S}$ rDNA ITS is able to detect and analyze the presence of $B$. glumae without DNA extraction or agar gel electrophoresis. PCR is considered able to convert and count small amounts of bacteria-infected seeds, even though asymptomatic (Nandakumar et al., 2009). The ITS method was carried out by Handiyanti et al. (2018) to detect the rice varieties infected by $B$. glumae in several locations in Java, the ITS primer can be used for early detection of $B$. glumae in rice seed. Detection of seeds infected by pathogens is also needed through strengthening the role of the agricultural quarantine officer at the entrance and exit of the seeds as well as the existing seed supervision and certification officer. In the field, detection and monitoring can be carried out by the Plant Pest Monitoring Officer (POPT) in each area. Detection in the field needs to be done on time to prevent the diseases spread to other plants. Therefore, the selection of the kit in detecting the disease is necessary.

\section{CONTROL STRATEGIES AND ANTICIPATIVE STEPS}

Quarantine is the first step to be implemented to prevent the spread of grain rot caused by $B$. glumae. An indication of the entry of $B$. glumae from several exporting countries certainly gives an idea to be able to strengthen the front gate of the Technical Implementation Unit of the Agricultural Quarantine Agency. Rapid detection methods need to be applied hence the type of pest infected the rice seed can be detected. In addition, the role of quarantine in preventing $B$. glumae between regions in Indonesia must be optimized. The status of $B$. glumae is become important disease of rice (OPTP), indicates that this disease has existed in several regions in Indonesia and its spread must be prevented. Quick steps are needed to determine the right control strategy in the 
field thus farmers can conduct the control technique immediately if rice plants are infected with grain rot.

Research on B. glumae in Indonesia is still limited and only becomes the object of monitoring by the Agricultural Quarantine Agency. Therefore, when an attack occurs in the field, effective control procedures can not yet be carried out. Kim et al. (2012) reported that controlling B. glumae is very difficult to do so that only practical methods can be recommended, i.e. through the use of pathogen-free seeds, cultural practices, and the use of resistant varieties. Early detection methods need to be established by seed health test and certification agencies in each region. Therefore, in addition by having the knowledge of disease monitoring and detection in the field, the proper disease detectors are needed to be used by the field officers to detect the cause of the disease.

Control techniques to prevent the spread of disease can be done by using resistant varieties. Krausz (2005) reported that the use of resistant varieties may become a promising technique to control B. glumae. The results of his study showed that each cultivar has a different level of resistance against $B$. glumae infection. These results were similar to Sayler et al. (2006) which stated that Drew varieties and LM-1 lines are relatively resistant to B. glumae (Figure 3A), whereas Krausz (2005) showed that Saber and Jefferson cultivars are more resistant to B. glumae and BF4-274 line also has resistant characteristics (Figure 3B). The results showed that 2 weeks after inoculation, each variety had different resistance. Based on these results, the use of resistant varieties may become an alternative control technique to suppress disease attacks. However, some rice varieties produced by Balitbangtan do not yet have specific resistant characteristics to B. glumae. Thereby, in the future, the breeding of resistant rice varieties in Indonesia to several plant quarantine pests, not only to control important pests, are necessitated to be done.

Several studies have shown that seed treatment is the most effective effort to prevent the attack of $B$. glumae. This was confirmed by Belmar et al. (2014) reported that an effective control strategy to suppress B. glumae is through seed treatment without reducing seed germination. According to him, several methods of seed treatment can be used, i.e. through the use of chemicals, heating technology, and seed washing (Table 1). Previously, Iwai et al. (2002) proved that the transfer of thionin-expressing genes from oats to rice plants was effective in suppressing $B$. glumae. Table 1 showed that several technologies can be used to control $B$ glumae. The use of garlic extract for seed treatment can be performed to suppress $B$. glumae infection. However, the reduction in the germination to be $70 \%$ is still being reconsidered. The results of the applied test conducted by Barantan (2015) also proved that the combination of hot water and bactericidal treatments can be recommended as quarantine treatment on rice seeds to eliminate $B$. glumae. The treatment of hot water at $56^{\circ} \mathrm{C}$ for 30 minutes followed by soaking into a copper hydroxide solution at a concentration of $2000 \mathrm{ppm}$ for 60 minutes and drying at $40^{\circ} \mathrm{C}$ for 24 hours effectively eliminating $B$. glumae without reducing seed viability. As for applications in the field, further research is still needed to determine the pesticide efficacy to control B. glumae. According to Zhou-qi et al. (2016), spraying bactericide and treating seeds with oxolinic acid proved to be effective in
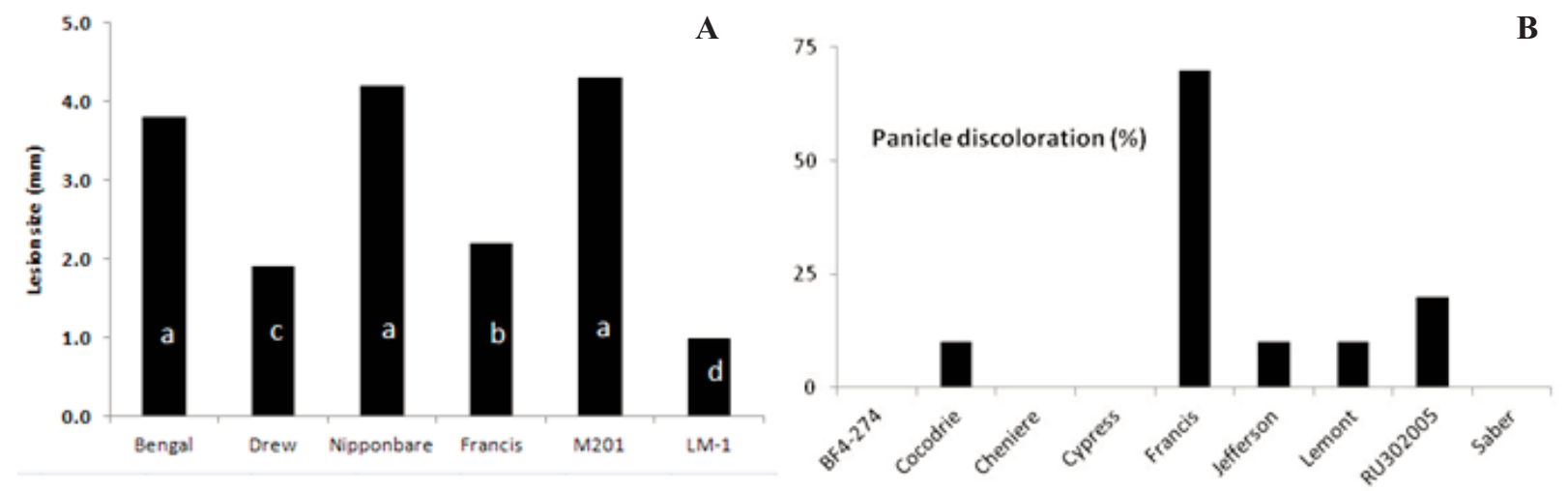

Figure 3. The lesion size on the rice (A) and panicle discoloration (B) in varying varieties and lines of rice (Krausz, 2005; Sayler et al., 2006) 
Table 1. Control techniques to suppress Burkholderia glumae in seed treatment

\begin{tabular}{lcccc}
\hline \multicolumn{1}{c}{ Control technique } & $\begin{array}{c}\text { Concentration/ } \\
\text { Temperature }\end{array}$ & Time (hour) & $\begin{array}{c}\text { Percentage of } \\
\text { infected seeds }\end{array}$ & $\begin{array}{c}\text { Percentage of } \\
\text { germination }\end{array}$ \\
\hline Control (B. glumae) & - & - & 100 & 90 \\
Heating & $55^{\circ} \mathrm{C}$ & 72 & 0 & 90 \\
Hot water treatment & $55^{\circ} \mathrm{C}$ & 0.025 & 15 & 50 \\
Cold temperature & $-20^{\circ} \mathrm{C}$ & 48 & 100 & 0 \\
Vinegar & $2 \%$ & 72 & 45 & 18 \\
Klorox + heating at $52^{\circ} \mathrm{C}$ & - & 0.17 & 30 & 90 \\
Garlic extract & $1.5 \mathrm{ml} / 3$ g seed & 1 & &
\end{tabular}

Source: Belmar et al. (2014)

suppressing B. glumae. But later according to him, this chemical leads the resistant strains of $B$. glumae.

\section{CONCLUSION}

Early detection of B. glumae is needed as an effort to prevent the spread of disease in rice plantations in Indonesia. Detection of B. glumae can be done through observing symptoms and identifying pathogenic characteristics through the use of selective media and PCR technology. Detection on the source of the disease can be conducted by the Agricultural Quarantine Agency as the front guard to detect the process of entry of rice seeds infected by $B$. glumae, originating from abroad or from regions in Indonesia. Detection in the field can be done through routine monitoring in several centers of rice cultivation areas that have indicated the presence of pathogens. Strengthening the ability of the field to be able to overcome the problem of disease attack in the field is also necessary to prevent disease development. The most effective control procedures for suppressing grain rot has not yet been found. Some efforts to suppress the disease can be done through the use of resistant varieties, seed treatment, heating technology, and the use of plant extracts that are known to be able to suppress $B$. glumae infections. As for applications in the field, it can be done by spraying bactericide or treating seeds with oxolinic acid. However, further studies are still needed to be able to apply by the farmers.

\section{LITERATURE CITED}

Alvarez, A.M. 2004. Integrated Approaches for Detection of Plant Pathogenic Bacteria and Diagnosis of Bacterial Disease. Annual Review of Phytopathology 42: 339-366.
Andrews, J.H, \& R.F. Harris. 2000. The Ecology and Biogeography of Microorganisms on Plant Surfaces. Annual Review of Phytopathology 38: 145-180.

[Barantan] Badan Karantina Pertanian. 2015. Laporan Tahunan Badan Karantina Pertanian 2014. Badan Karantina Pertanian, Jakarta. 395 p.

Ballard, R.W., N.J. Palleroni, M. Doudoroff, \& R.Y. Stanier. 1970. Taxonomy of the Aerobic Pseudomonads: Pseudomonas cepacia, $P$. marginata, $P$. alliicola and $P$. caryophylli. Journal of General Microbiology 60: 199-214.

Belmar, S.B., C.D. Kelsey, T.A. Gebremariam, \& Y.A. Wamishe. 2014. Seed Management to Control Bacterial Panicle Blight of Rice, p. 82-94. In R.J. Norman \& K.A.K. Moldenhauer (eds.), Arkansas Rice Research Studies 2014. Division of Agriculture. University of Arkansas Systems, Fayetteville.

CABI. 2017. Burkholderia glumae (Bacterial Grain Rot). http://www.cabi.org/isc/datasheet/44964, modified 19/01/2017.

Fang, Y., L. Xu, W. Tian, Y. Huai, S. Yu, M. Lou, \& G. Xie. 2009. Real-time Fluorescence PCR Method for Detection of Burkholderia glumae from Rice. Rice Science 16: 157-160.

Furuya, N.,H. Ura, K. Iiyama, M. Matsumoto, M. Takeshita \& Y. Takanami. 2002. Specific Oligonucleotide Primers Based on Sequences of the $16 \mathrm{~S}-23 \mathrm{~S}$ rDNA Spacer Region for the Detection of Burkholderia gladioli by PCR. Journal of General Plant Phytopathology 68: 220-224.

Goto, K. \& K. Ohata. 1956. New Bacterial Diseases of Rice (Brown Stripe and Grain Rot). Annual Phytophatology Society of Japan 21: 46-47.

Ham, J.H., M.C. Rush, \& R.A. Melanson. 2011. Burkholderia glumae: Next Major Pathogen of Rice? Molecular Plant Pathology 12: 329-339. 
Handiyanti, M., S. Subandiyah, \& T. Joko. 2018. Deteksi Molekuler Burkholderia glumae, Penyebab Penyakit Hawar Malai Padi. Jurnal Perlindungan Tanaman Indonesia 22: 98-107.

Hikichi, Y., K. Tsujiguchi, Y. Maeda, \& T. Okuno. 2001. Development of Increased Oxolinic AcidResistance in Burkholderia glumae. Journal of General Plant Pathology 67: 58-62.

Iiyama, K., N. Furuya, Y. Takanami, \& N. Matsuyama. 1995. A Role of Phytotoxin in Virulence of Pseudomonas glumae Kurita et Tabei. Japanese Journal of Phytophatology 61: 470-476.

Iwai, T., H. Kaku, R. Honkura, S. Nakamura, H. Ochiai, T. Sasaki, \& Y. Ohashi. 2002. Enhanced Resistance to Seed-Transmitted Bacterial Diseases in Transgenic Rice Plants Overproducing an Oat Cell-Wall-Bound Thionin. Molecular Plant-Microbe Interactions 15: 515-521.

Jeong, Y., J. Kim, S. Kim, Y. Kang, T. Nagamatsu, \& I. Hwang. 2003. Toxoflavin Produced by Burkholderia glumae Causing Ricegrain Rot is Responsible for Inducing Bacterial Wilt in Many Field Crops. Plant Disease 87: 890-895.

Kawanishi, T., T. Shiraishi, Y. Okano, K. Sugawara, M. Hashimoto, K. Maejima, K. Komatsu, S. Kakizawa, Y. Yamaji, H. Hamamoto, K. Oshima, \& S. Namba. 2011. New Detection Systems of Bacteria Using Highly Selective Media Designed by SMART: Selective Medium Design Algorithm Restricted by Two Constraints. PLoS ONE 6: 1-10.

Kawaradani, M., K. Okada, \& S. Kusakari. 2000. New Selective Medium for Isolation of Burkholderia glumae from Rice Seeds. Journal of General Plant Pathology 66: 234-237.

Kim, J., Y. Kang, JG Kim, O. Choi, \& I. Hwang. 2010. Occurrence of Burkholderia glumae on Rice and Field Crops in Korea. Plant Pathology Journal 26: 271-272.

Kim, B.K., M.S. Cho, M.H. Kim, H.J. Choi, M.J. Kang, H.S. Shim, T.Y. Ahn, J. Kim, \& D.S. Park. 2012. Rapid and Specific Detection of Burkholderia glumae in Rice Seed by Real-Time Bio-PCR Using Species-Specific Primers Based on an rhs Family Gene. Plant Disease 96: 577580 .

Krausz, J.P. 2005. Management of Bacterial Panicle Blight Caused by Burkholderia glumae. TRRF Report on 2005 Research. Department of Plant Pathology, Texas A\&M University. Texas. 4 p.
Kurita, T., H. Tabei, \& T. Sato. 1964. A Few Studies on Factors Associated with Infection of Bacterial Grain Rot of Rice. Annual Phytopathology Society of Japan 29: 60.

Mew, T. W. 1992. Grain Rot. p. 9. In R.K. Webster \& P.S. Gunnell. (eds.), Compendium of Rice Diseases. APS Press, St. Paul, MN.

Zeigler, G.S., \& E. Alvarez. 1990. Characteristics of Pseudomonas spp. Causing Grain Discoloration and Sheath Rot of Rice, and Associated Pseudomonas Epiphytes. Plant Disease 74: 917-922.

Mizobuchi, R., H. Sato, S. Fukuoka, T. Tanabata, S. Tsushima, T. Imbe, \& M. Yano. 2013. Mapping a Quantitative Trait Locus for Resistance to Bacterial Grain Rot in Rice. Rice 6: 13.

Nandakumar, R., A.K.M. Shahjahan, X.L. Yuan, E. Dickstein, D.E. Groth, C.A. Clark, R.D. Cartwright, \& M.C. Rush. 2009. Burkholderia glumae and B. gladioli Cause Bacterial Panicle Blight in Rice in the Southern United States. Plant Disease 93: 896-905.

Nghiep, H.V., P.V. Du, \& S.B. Mathur. 2001. Effect of Cleaning on Seed Health and Seed Germination of Rice. Omonrice 9: 138-139.

Niño, B.C.J.S. 2014. Identificación Molecular de Burkholderia glumae, Causante del Añublo Bacterial, en Cinco Zonas Arroceras de Nicaragua. Universidad Nacional Agraria Facultad de Agronomía. Nicaragua. $23 \mathrm{p}$.

Peraturan Menteri Pertanian (Permentan) No. 51 Tahun 2015. Perubahan Atas Peraturan Menteri Pertanian Nomor 93/Permentan/OT.140/12/2011 Tentang Jenis Organisme Pengganggu Tumbuhan Karantina.

Peraturan Menteri Pertanian (Permentan) Nomor 31/PERMENTAN/KR.010/7/2018. Perubahan Kedua Atas Peraturan Menteri Pertanian Nomor 93/Permentan/OT.140/12/2011 Tentang Jenis Organisme Pengganggu Tumbuhan Karantina.

Pinson, S.R.M., A.K.M. Shahjahan, M.C. Rush, \& D.E. Groth. 2010. Bacterial Panicle Blight Resistance QTLs in Rice and their Association with Other Disease Resistance Loci and Heading Date. Crop Science 50: 1287-1297.

Rush, M.C. 2007. A Field Test of Two Non-pathogenic, Genetically Engineered Mutant Strains of Burkholderia glumae. U.S. Department of Agriculture Animal and Plant Health Inspection Service Biotechnology Regulatory Services. 26 p. 
Saddler, G.S. 1994. IMI Descriptions of Fungi and Bacteria, Set 122, Nos 1211-1220. Mycopathologia 128: 59-60.

Sayler, R.J, R.D. Cartwright, \& Y. Yang. 2006. Genetic Characterization and Real-Time PCR Detection of Burkholderia glumae, a Newly Emerging Bacterial Pathogen of Rice in the United States. Plant Disease 90: 603-610.

Shahjahan, A.K.M., M.C. Rush, D.E. Groth, C.A. Clark. 2000a. Panicle Blight. Rice Journal 15: 26-29.

Suzuki, F., H. Sawada, K. Azegami, \& K. Tsuchiya. 2004. Molecular Characterization of the Tox Operon Involved in Toxoflavin Biosynthesis of Burkholderia glumae. Journal of General Plant Pathology 70: 97-107.

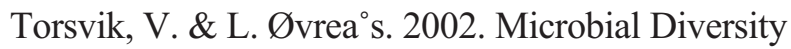
and Function in Soil: From Genes to Ecosystems. Current Opinion on Microbiology 5: 240-245.

Trung, H.M., N.V. Van, N. V. Vien, D. T. Lam, \& M. Lien. 1993. Occurrence of Rice Grain Rot Disease in Vietnam. International Rice Research Notes 18: 30.

Tsushima, S., S. Mogi, \& H. Saito. 1986. Effect of Temperature on the Growth of Pseudomonas glumae and the Development of Rice Bacterial Grain Rot. Association Plant Protection Kyushu 32: 14-16.

Tsushima, S., H. Naito, \& M. Koitabashi. 1995. Change in Panicle Susceptibility Associated with Flowering Rate of Spikelets in Bacterial Grain Rot of Rice Caused by Pseudomonas glumae. Annual Phytopathology Society of Japan 61: 109-113.
Tsushima, S. 1996. Epidemiology of Bacterial Grain Rot of Rice Caused by Pseudomonas glumae. JARQ 30: 85-89.

Tsushima, S. 2011. Study on Control and Epidemiology of Bacterial Grain Rot of Rice. Journal of General Plant Pathology 77: 358-360.

Tsushima, S., S. Wakimoto \& S. Mogi. 1986. Selective Medium for Detecting Pseudomonas glumae Jurita et Tabei, the Causal Bacterium of Grain Rot of Rice. Annual Phytopathology Society of Japan 52: 253-259.

Uematsu, T., D. Yoshimura, K. Nishiyama, T. Ibaraki, \& H. Fujii. 1976. Occurrence of Bacterial Seedling Rot in Nursery Flat, Caused by Grain Rot Bacterium Pseudomonas glumae. Annual Phytopathology Society of Japan 42: 310-312.

Yuan, X. 2004. Identification of Bacterial Pathogens Causing Panicle Blight of Rice in Louisiana. Thesis. The Department of Plant Pathology and Crop Physiology, Graduate Faculty of the Louisiana State University and Agricultural and Mechanical College, Louisiana. 97 p.

Zhou, X.G, A.M. McClung, M.O. Way, Y. Jo, R.E. Tabien, \& L.T. Wilson. 2011. Severe Outbreak of Bacterial Panicle Blight Across Texas Rice Belt in 2010. Phytopathology 10: S205.

Zhou-qi, C., Z. Bo, X. Guan-lin, L. Bin, \& H. Shi-wen. 2016. Research Status and Prospect of Burkholderia glumae, the Pathogen Causing Bacterial Panicle Blight. Rice Science 23: 111-118. 